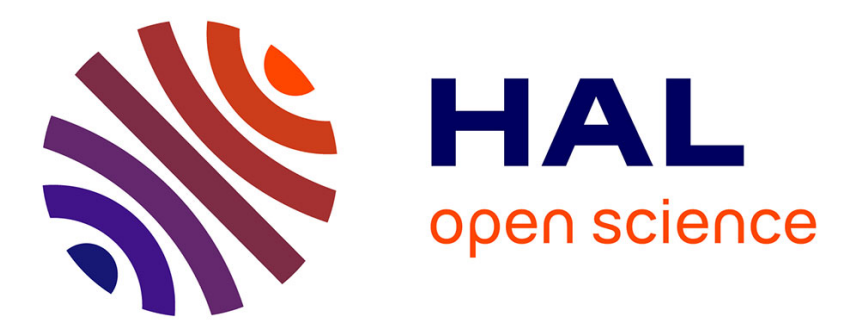

\title{
A history of long-term human-environment interactions in the French Pyrenees inferred from the pollen data
}

Didier Galop, Damien Rius, Carole Cugny, Florence Mazier

\section{To cite this version:}

Didier Galop, Damien Rius, Carole Cugny, Florence Mazier. A history of long-term humanenvironment interactions in the French Pyrenees inferred from the pollen data. Continuity and change in cultural adaptation to mountain environments. From prehistory to contemporary threats, pp.19-30, 2013. hal-01236311

\section{HAL Id: hal-01236311 https://hal.science/hal-01236311}

Submitted on 1 Dec 2015

HAL is a multi-disciplinary open access archive for the deposit and dissemination of scientific research documents, whether they are published or not. The documents may come from teaching and research institutions in France or abroad, or from public or private research centers.
L'archive ouverte pluridisciplinaire HAL, est destinée au dépôt et à la diffusion de documents scientifiques de niveau recherche, publiés ou non, émanant des établissements d'enseignement et de recherche français ou étrangers, des laboratoires publics ou privés. 


\title{
Chapter 3
}

\section{A History of Long-Term Human-Environment Interactions in the French Pyrenees Inferred from the Pollen Data}

\author{
Didier Galop, Damien Rius, Carole Cugny, and Florence Mazier
}

\section{Introduction}

Over the last decade, several research programs have been involved in studying the socioecological history of the Pyrenean Mountains using sedimentary records preserved in lakes and bogs. Their main focus was on understanding human exploitation of natural resources and its environmental consequences. Recovering these "memories" buried for thousands of years in sediments requires interdisciplinary efforts dealing with the analysis of a large number of bio-indicators. The study of those bio-indicators has become a multi-proxy process which combines the classical study of fossil pollen and spores with macro-charcoal (size $>150 \mu \mathrm{m}$ ) and nonpollen palynomorphs (algae, fungal spores, etc.) data. Those additional bio-indicators provide precise information about the historical use of fire (Whitlock and Larsen 2002; Vanniere et al. 2001; Galop et al. 2002; Rius et al. 2009) as well as trophic conditions or grazing activities respectively (van Geel 2001; Cugny et al. 2010). Along researching those biomarkers, geochemical studies of lead isotopes helped in documenting past atmospheric pollution events related to historical mining or metallurgical activities (Bindler et al. 1999; Brännvall et al. 1999; Galop et al. 2001; Monna et al. 2004). Leaving aside the technical aspects of those studies, we briefly introduce below the principles of the palynological approach as a means of tracing the impact of human past activities on the local ecosystem. This approach takes into account a series of anthropogenic pollen indicators. The most obvious signature of human activity is deforestation associated with the conquest

D. Galop $(\triangle) \bullet$ C. Cugny $\bullet$ F. Mazier

Laboratoire GEODE, UMR 5602 CNRS, Université Toulouse 2,

Toulouse cedex 9, Toulouse 31058, France

e-mail: didier.galop@univ-tlse2.fr

D. Rius

Laboratoire Chrono-Environnement, UMR 6249 CNRS,

Besançon cedex 25030, France 
of land highlighted in the pollen diagrams by lower frequencies of tree species and by the higher frequencies of herbaceous and some tree species, which prefer colonizing disturbed areas (juniper, birch, hazel, etc.). However, such events may also be caused by other factors unrelated to human activity (weather hazards, natural fires, etc.). Therefore identification of other pollen indicators undoubtedly associated with human actions is needed. We propose using the indicator-species approach derived from ethnobotanical investigations and based on modern pollen representation of cultigens and other plants characteristic of agro-pastoral practices (Behre 1981, 1986; Mazier et al. 2006, 2009). Cultivated species, arable weeds as well as ruderal plants found in areas impacted by past human activities such as fallows, waste ground, surroundings of buildings are considered to be such reliable indicators. Variations of taxon-guides can help us to understand the long-term fluctuations of human-induced pressure at a given site and allow their interpretation in terms of spread, stability, or abandonment of human activities. Such approach has been applied to identify the main phases and processes of human impact on the northern (French side) slopes of the Pyrenees (Fig. 3.1). This chapter offers an overview of the last 7,000 years of human history in those mountains with a particular focus on the arrival of the Neolithic agro-pastoralists.

\section{The Neolithic Conquest}

The introduction of agro-pastoral culture in the Pyrenees and the spread of that culture which significantly affected the local ecosystem and contributed to environmental changes cannot be disconnected from the Neolithization process that affected the entire Mediterranean Basin. The palynological data acquired during the last 30 years of research conducted on the northern slopes of the Pyrenees help us to understand environmental changes of the landscape but also provide the pollen evidence on human impacts on the ecosystem. Those impacts, namely the appearance of grains or plants associated with agro-pastoral activities, as well as signs of openings in the forest allow us to infer the chronology and the spatial extent of the early agropastoral activities across the mountains. The spatiotemporal analysis of the appearance of early agro-pastoralists in the region clearly indicates that the Neolithic conquest of the Pyrenees was not a uniform process (Fig. 3.2). The spread of human Neolithic activities across the Mediterranean and the Atlantic coasts was characterized by asymmetric diffusion processes regularly influenced by what was happening in the Mediterranean zone, and an arrhythmic phase of expansion, whose origin still uncertain may have been driven by sociocultural and natural phenomena (i.e., ecological thresholds).

The earliest Neolithic signs of human impact on the foothills of the Mediterranean Pyrenees are confirmed by pollen data from the seventh and the turn to sixth millennium BC, 6700-5900 cal. BC, in the lower Aude Valley (Roussillon plain), i.e., several centuries before the dates of the first Neolithic archaeological evidence assessed 


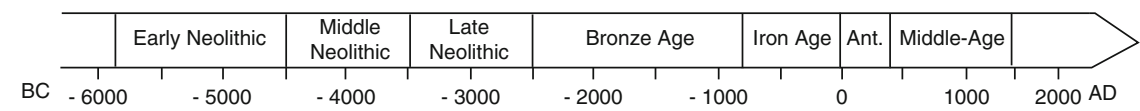

a Agriculture

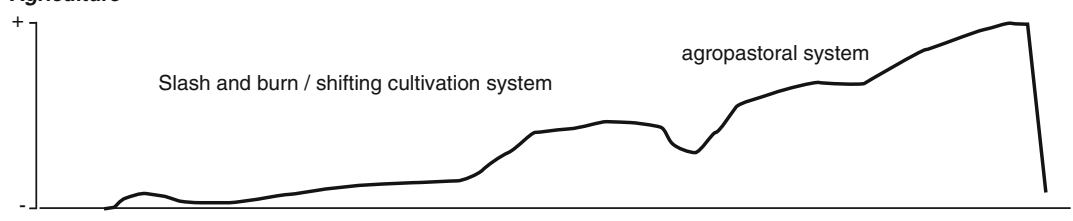

b Grazing

Seasonal habitats and burials at high altitude

Transhumant pastoralism

Mobile pastoralism Seasonal occupation of caves Nomadic pastoralism by pastoralist m
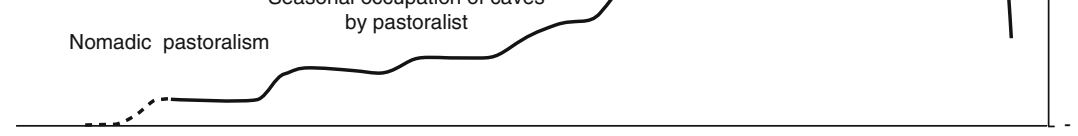

C Fires (human-induced)

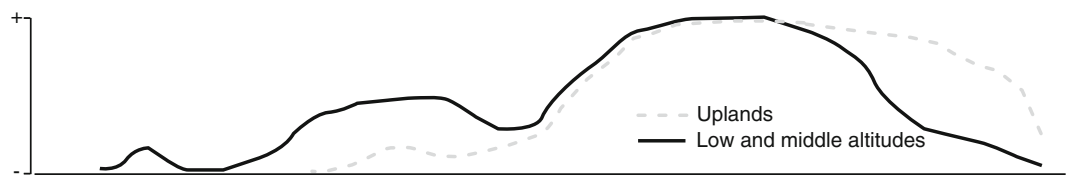

d Mining and metallurgy

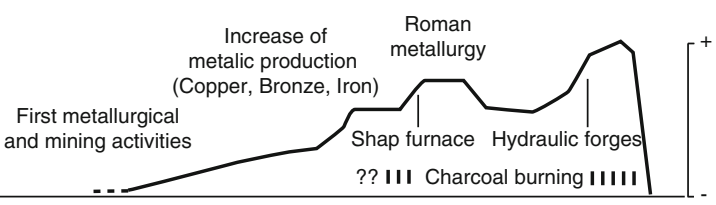

e Woodlands

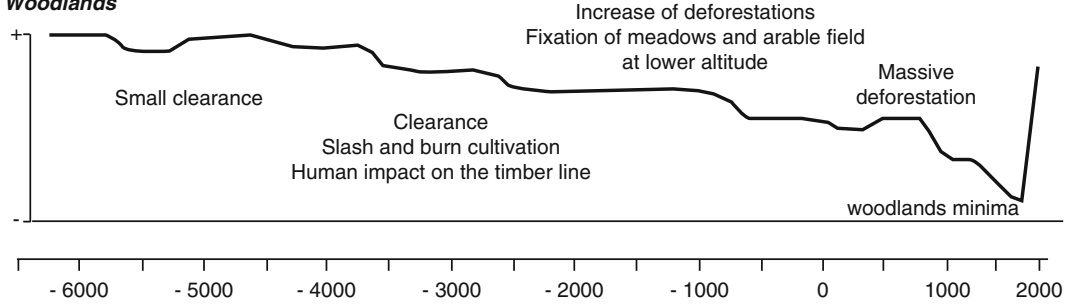

Fig. 3.1 Synthesis of long-term socio-ecological history on the northern slope of the Pyrenees during the last 8,000 years inferred from palaeoecological and archaeological data

between 6400 and 6000 cal. BC in Catalonia's lowlands (Planchais 1985; Jalut 1995; Guenet 1995; Galop and Vaquer 2004). The first discrete manifestation of the presence of the Neolithic societies linked to the appearance of the Cardial Ware groups in the Pyrenees is dated to 5800-5500 cal. BC, and reinforced by the data on an opening of the oak forest due to the emergence of agriculture. From the Mediterranean center the economy based on agricultural production gradually spread out across the Pyrenees at the end of the sixth and the beginning of the fifth millennium BC. 

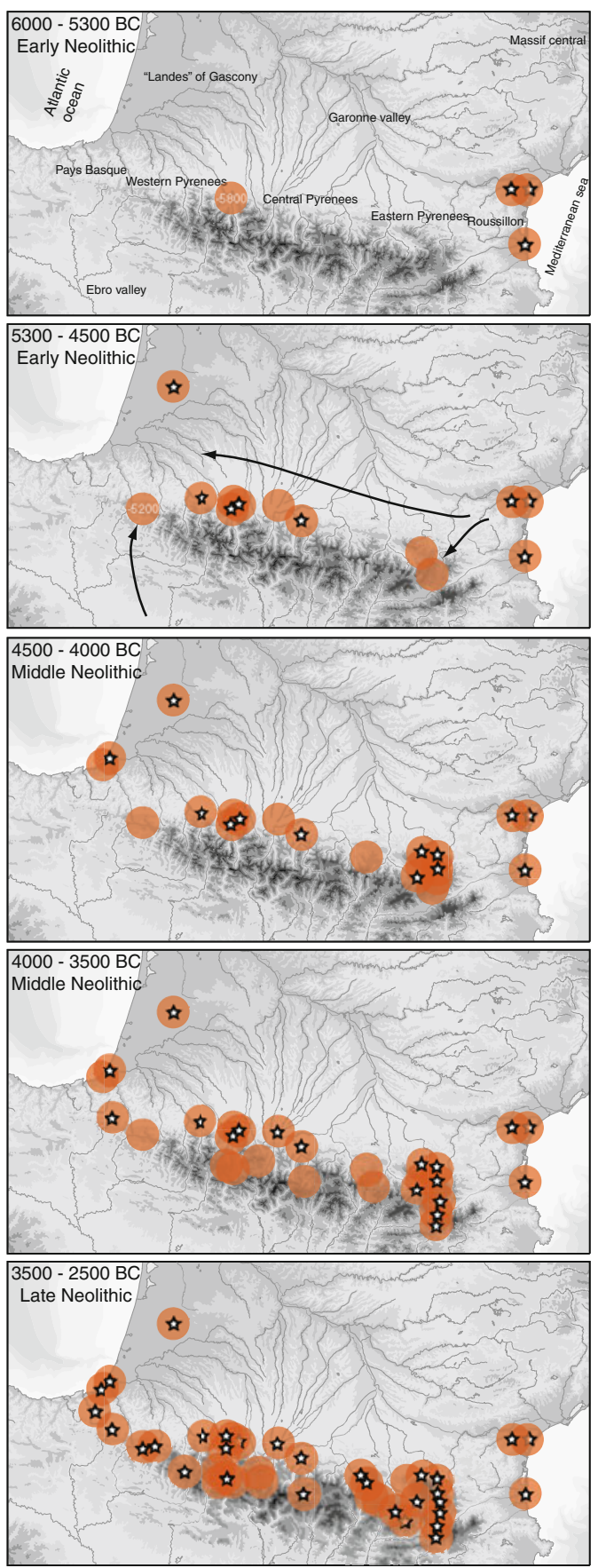

Fig. 3.2 Dissemination of agro-pastoral activities on the northern slope of the Pyrenees during the Neolithic period inferred from pollen records. Coloured discs report first evidence of grazing activities suggested by the presence pollen of nitrophilous plants while the stars indicate the first notations of cereal cultivation 
The diffusion of agro-pastoral culture into the Pyrenees remains difficult to date precisely. This is especially true for the initial stages and their study requires a lot of care and attention because the anthropogenic signature loses its strength with increasing distance from the Neolithic centers located on the Mediterranean coast. The earliest agro-pastoral communities may have operated at a scale too small, or below a disturbance threshold, to be detectable by pollen analysis and thus their activities remain a "blind spot" in our history. Although such possibility is real, the pollen data suggest that human groups appeared ca. $5800 \mathrm{cal}$. BC at lower altitudes in the piedmont of the northern Pyrenees (Galop 2005; Rius et al. 2009). The southern slopes (Spanish side), however, have been colonized by the Neolithic societies more rapidly. Deforestation and cultivated crops were detected in the immediate vicinity of the archaeological site of Chaves, located in the southern part of the Pyrenees and dated between 5800 and 5300 cal. BC (Lopez-Garcia and Lopez-Saez 2000). Was the Ebro Valley an important geographical axis of cultural diffusion that allowed the rapid expansion of agro-pastoral culture on the southern side? This is likely and researching this hypothesis may also explain the appearance of anthropogenic pollen indicators ca. $5200 \mathrm{cal} \mathrm{BC}$ in the highlands of the Basque Mountains, upstream of the upper Ebro Valley. In this highland zone, slender indices of temporary occupation and pastoral opening of the oak forest are present in the pollen record obtained at Artxilondo near the Aizpea cave, where a Neolithic occupation dated to 5400-5200 cal. BC has been recorded (Barandiaran and Cava 2002; Galop et al. 2004). These activities occurred few centuries before the first evidence of human Neolithic activity on the northern slopes and are most likely linked to small groups of hunter and pastoralist nomads penetrating the high altitudes. However, such impacts remain isolated and agricultural activities in the Pyrenees seem absent in the western, Atlantic regions of the mountains during the early phase of Neolithization.

During the second half of the Early Neolithic Period human activities progressed slowly along the mountain range and are better visible in the pollen record of the northern Pyrenean foothills (Rius et al. 2009). The first traces of agriculture associated with small forest openings are identified in the western and central Pyrenean foothills ca. 4800 cal. BC. At the same time similar traits are recorded further north in Landes Department in Gascony (Faure and Galop 2011). Irregular presence of pollen grains from ruderal species recorded at several sites in the foothills of the Garonne Valley and dated between 4800 and $4500 \mathrm{cal}$. BC, attests to the emergence or intensification of agro-pastoral activities in lowland areas.

The diffusion of the agro-pastoral culture during the early Neolithization to the central and western Pyrenees appears restricted to the foothills, whereas at the same time it is well represented in the mountain areas of the eastern, Mediterranean part of the mountains. Pollen evidence of pastoral activities and forest clearings that took place between 4700 and $4500 \mathrm{cal}$. BC were observed in higher altitudes of the eastern Pyrenees ( $>1,500 \mathrm{~m}$ above sea level [m.a.s.l.]). This observation reinforces the hypothesis of the spread of agro-pastoral culture in the foothills of Catalonia along the eastern Pyrenees (Baldellou and Utrilla 1999). The data also highlight the apparent 
slowness of dissemination of the Neolithic culture into the central and western Pyrenees. This slow and asymmetrical diffusion could have been caused by difficulties in adaptation to different ecological conditions by communities arriving from otherwise sparse Neolithic settlements of the Mediterranean region.

Following this pioneering phase, the spread of the agro-pastoral culture across the Pyrenean Mountains becomes more evident during the Middle Neolithic. It coincides with the rise of the Chasseen culture linked to an increase of population and settlements in regions outside the Pyrenees (Guilaine 2003). The occurrence of agro-pastoral pollen indicators on the Atlantic coast at ca. $4400 \mathrm{cal}$. BC suggests the conclusion of the diffusion process of agro-pastoral lifestyle along the northern Pyrenean foothills and suggests that the highlands may have been subsequently occupied in the phase between 4200 and 3700 cal. BC.

The first palynological evidence of agricultural lifestyle such as grazing and forest disturbance in the western Pyrenees, indicated by an increase in the frequency of fire, is confirmed for the period ca. 4200-4100 BC (Galop et al. 2001; Rius et al. 2009). Further east, in the central Pyrenees and Ariege, several pollen records obtained from altitudes between 1,500 and 2,100 m.a.s.l. show some signs of deforestations and evidences of pastoral activities during the same period (Jalut et al. 2000; Galop 1998; Galop and Vaquer 2004). Nevertheless, it is in the eastern Pyrenees that the expansion of the Middle Neolithic culture is the best evidenced with several records showing the onset of human impact between 4200 and 4000 cal. BC. These records demonstrate a significant wave of human colonization of the mountain area, which continued until around 3700-3600 cal. BC.

The expansion of agro-pastoral culture into the Pyrenean highlands is not unique and is a part of a larger phenomenon which concerns all European mountain environments (Walsh et al. 2007, 2008; Walsh and Richer 2006). During the Middle Neolithic evidence of animal husbandry practiced in the mountains appeared. Pastoral practices are clearly documented for this period in the Pyrenees by both archaeological evidences and the occurrences of pollen from nitrophilous species associated with grazing (ribgrass (Plantago lanceolata), common nettle (Urtica dioica), common poppy (Chenopodium album), or sorrels (Rumex sp.)). Additionally, shepherd's huts dated to ca. $4200 \mathrm{cal}$. BC and fossilized coprolites (ca. $3800 \mathrm{cal}$. BC) including archaeozoological remains have been discovered above 2,000 m.a.s.l. in the eastern Pyrenees (Rendu 2003) and in the cave site of Mikelauen-ziloa in the Basque Country (Marembert 2000). They represent valuable evidence of pastoral exploitation of the Pyrenees at the turn of the fifth and fourth millennia BC. Whether these were true pastoral practices is still debatable. It seems, however, that they might have been associated with the beginnings of seasonal transhumance practices from low to high altitude areas. If the above evidence will be confirmed by other research, a hypothesis that the Middle Neolithic Period may represent the birth of highland pastoral lifestyle of Pyrenean societies is worth pursuing. Time investments in building shepherds huts (Rendu 2003) and the regular use of caves to shelter livestock might suggest a more sedentary way of life and not strictly nomadic, as evidenced by ethnographic data. 
Based on the above evidence, we can state without much doubts that the period 4200-3700 cal. BC represents the first phase of territorial expansion of agropastoral culture in the Pyrenees, but we must emphasize that this period is characterized by minor human impact on the environment. Despite the fact that palaeoecological data, more precisely macrocharcoal analysis, support the existence of slash-and-burn agriculture at that time (Galop et al. 2002; Rius et al. 2009) and also the expansion of livestock, analyses of pollen data also suggest local deforestation and a rapid regeneration of the oak forest even in the subalpine pine forest. Further observations concerning the economic sustainability of this period suggest a decrease in agro-pastoral activities between 3700 and 3300 cal. BC. This retreat or abandonment of human agro-pastoral activities recorded during the transition from the Middle and Late Neolithic (ca. 3300 cal. BC) correlated with a climatic decline suggested by advances of the Pyrenean and Alpine glaciers (Gellatly et al. 1992; Haas et al. 1998). This correlation reinforces the hypothesis on the influence of climate variability on human activity and land-use in highland zones (Berglund 2003; Bonsall et al. 2002; Gobet et al. 2003; Tinner et al. 2003; Magny 2004; Galop 2005).

The phase of abandonment of agro-pastoral lifestyle (3700-3300 cal. BC) is followed by another increase registered at ca. $3300 \mathrm{cal}$. BC and visible in the majority of pollen records over the Pyrenean chain. This second expansion of Neolithization, also recorded elsewhere in Europe and the Mediterranean, represents a significant cultural change. The palynological evidences of agricultural and grazing activities of the time increased and became more regular. This indicates an intensification of pastoral pressure in high altitudes, including the areas that had not been previously exploited (Galop 1998, 2001). The increase of human activity related to land-use during this period is confirmed by pollen data and fire events linked to shifting and slash-and burn cultivation. Those activities have indeed considerably increased from 3300 cal. BC in both the piedmont and at the timber line (Galop et al. 2002, 2003; Vanniere et al. 2001; Rius et al. 2009). In addition, by the end of the Neolithic Period, geochemical analyses performed in several peat deposits show the first inputs of lead deposition at ca. 2500 cal. BC. Such deposition strongly suggests mining and metallurgical activities, which are also responsible for an increase in woodland exploitation for the production of charcoal (Galop and Jalut 1994; Galop et al. 2001; Monna et al. 2004; Beyrie et al. 2003).

\section{The Bronze Age: A Turning Point}

Pollen data demonstrates the existence of two distinct phases of mountain population growth, first in the beginning of the Bronze Age around $2000 \mathrm{BC}$, and second during the Bronze Age - Iron Age transition around 1000 BC, (Carozza et al. 2005; Galop et al. 2007; Carozza and Galop 2008). This population change is visible synchronously in all the pollen records along the mountain chain revealing a 
regional-scale social process that took place 4,000 years ago. An increase of the population density at this time is shown by the abundance of archaeological remains of pastoral shelters recently discovered over 2,000 m.a.s.1. in the eastern and central Pyrenees (Rendu 2003; Rendu et al. in press). The increase of human pressure on woodlands is reflected in sedimentary record for this period. They show a rise in fire events linked to land use changes (Rius et al. 2009), while geochemical data from the Basque Country and the Ossau Valley stress an intensification of metallurgical and/or mining activities.

During the Iron Age, pollen data indicates altitude-dependent trajectories of human activities. From about 800 cal. BC, pollen records from the uplands show an abandonment phase that is not recorded at low altitudes. Conversely, there seems to be a continuation of relatively stable human land-use pressure in lowlands. This apparent lack of interest in upland areas remains difficult to explain. One possibility might be climatic change as this abandonment phase corresponds with a climatic deterioration around 850 BC (van Geel et al. 1996, 1998; Galop et al. 2007). But could climate change have forced the Pyrenean populations to retreat to warmer areas as it has been shown for the northern Alps? The answering of this question still awaits archaeological data. Also, socioeconomic and/or political forces may have caused such abandonment. Without offering a definitive answer to these questions, research conducted in the central Pyrenees seems to demonstrate the existence of a short period around 850 cal. $\mathrm{BC}$ during which weather conditions deteriorated. The degradation of the climate was significant enough that increased snowfall and lower annual temperatures allowed the maintenance of large snowfields at 2,000 m.a.s.l. during summertime (Carozza and Galop 2008). Such conditions would have certainly been a limiting factor to the exploitation of highland pastures thereby forcing population to retreat to intermediate altitude areas where conditions would have been more favorable for livestock grazing.

\section{From Ancient Lifestyles to the Construction of Medieval Landscapes}

Contrary to common claims that the culture change associated with the Roman Period was a fundamental step in the construction of cultural landscapes, this period does not represent a major phase in the environmental history of the Pyrenees. Antiquity in general is marked by a resurgence of human activities and pollen records clearly show a wide variety of historical trajectories. The environmental changes recorded in pollen samples from the Pyrenees indicate significant local deforestation probably driven by a socioecological pressure in which economic factors and pragmatism determined the approach in the management of natural resources (Galop 2005). Export of natural resources to the growing urban centers 
evidenced by, for instance, the presence of timber-floating channels may have been a factor limiting the exploitation of the arable land and pastures.

Late Antiquity and the Early Middle Ages unfairly regarded as periods of cultural decline or abandonment in several parts of Europe present different trends in the Pyrenees. Recent palynological studies have shown a rise of agropastoral activities during those periods in the central Pyrenees. The existing evidence suggest the colonization of new lands from the sixth century AD (Galop 2000) evidenced by an increase in fire events and deforestation in the altitudes between 700 and 1,300 m.a.s.l. and the presence of shepherd huts at high altitude (Rendu et al. in press).

The agro-pastoral expansion which begun in the sixth and seventh centuries becomes even more pronounced between the ninth and the tenth centuries. Although the signs of an explosion of agro-pastoral activities do not appear with the same clarity in all records, acceleration in deforestation in all altitudes is certain. Severe deforestations are caused by the establishment of pastoral monastic estates, the increase of cultivated lands, and the massive development of metallurgical activities supported by technological advances. In some cases this has led to the complete eradication of forests as it has been demonstrated in Haut-Ariège (Galop and Jalut 1994; Bonhôte et al. 2002).

This intensification of the agro-sylvo-pastoral system - the origin of modern Pyrenean landscapes - was slowed by a phase of depopulation in the fourteenth to fifteenth centuries. ${ }^{1}$ Palynological records showing reforestation reflect the effects of the medieval crisis linked to the plague and military conflicts. However, a closer examination of the data suggests that the consequences of this crisis were diverse in the Pyrenees. For example, reforestation does not occur in the Valley of Aston and in most of the metal-producing valleys of Haut-Ariege. Despite the existence of serious social problems such as epidemics in these valleys the valuable economy of metallurgical activities may have offset the negative effects, thus maintaining pressure on the local forests.

Following this medieval crisis, the effect of economic and demographic recoveries and new patterns of land-use are clearly detectable in the majority of pollen records from the research area. This phase, especially the Industrial Revolution, was responsible for significant deforestation which in some cases led to an ecological crisis. It was during this final phase of human expansion that Pyrenean agro-pastoral landscapes sustained the peak of human-induced pressure on the local environment. Today, an unprecedented phase of land abandonment initiated during the first half of the twentieth century has encouraged processes of ecological degradation that will gradually erase the agro-pastoral culture, but not its legacy recorded in the past.

\footnotetext{
${ }^{1}$ Editor's note: possibly related to the Little Ice Age in Europe.
} 


\section{References}

Baldellou, V., \& Utrilla, P. (1999). Le Néolithique en Aragon. Le Néolithique du Nord-ouest méditerranéen, XXIV ${ }^{\circ}$ Congrès Préhistorique de France (pp. 225-237).

Barandiaran, I., \& Cava, A. (2002). Cazadores-recolectores en el Pirineo navarro: el sitio de Aizpea entre 8000 y 6000 anos antes de ahora. Spain: Universidad del Pais Vasco.

Behre, K.-E. (1981). The interpretation of anthropogenic indicators in pollen diagrams. Pollen et spores, 23(2), 225-245.

Behre, K.-E. (1986). Anthropogenic indicators in pollen diagrams (p. 232). Rotterdam, Boston: A. A. Balkema.

Berglund, B. E. (2003). Human impact and climate changes-synchronous events and a causal link? Quaternary International, 105(1), 7-12.

Beyrie, A., Galop, D., Monna, F., \& Mougin, V. (2003). La métallurgie du fer au Pays basque durant l'Antiquité. Etat des connaissances dans la vallée de Baigorri (Pyrénées-Atlantiques). Aquitania., 19, 44-66.

Bindler, R., Brännvall, M.-J., Renberg, I., Emteryd, O., \& Grip, H. (1999). Natural lead concentrations in pristine boreal forest soils and past pollution trends: A reference for critical load models. Environmental Science and Technology, 33, 3362-3367.

Bonhôte, J., Davasse, B., Dubois, C., Izard, V., \& Métailié, J.-P. (2002). Charcoal kilns and environmental history in the eastern Pyrenees (France). In S. Thiébault (Ed.), Charcoal Analysis, Methodological approaches, Palaeocological results and wood uses (pp. 219-228). BAR International Series 1063.

Bonsall, C., Macklin, M., Anderson, D. E., \& Payton, R. W. (2002). Climate change and the adoption of agriculture in north-west Europe. European Journal of Archaeology, 5(1), 9-23.

Brännvall, M.-L., Bindler, R., Renberg, I., Emteryd, O., Bartnicki, J., \& Billström, K. (1999). The medieval metal industry was the cradle of modern large-scale atmospheric lead pollution in northern Europe. Environmental Science and Technology, 33, 4391-4395.

Carozza, L., \& Galop, D. (2008). Le dynamisme des marges. Peuplement et exploitation des espaces de montagne durant l'âge du Bronze. In J. Guilaine (Ed.), Villes, villages, campagnes de l'âge du Bronze (pp. 226-255). Editions Errance.

Carozza, L., Galop, D., Marembert, F., \& Monna, F. (2005). Quel statut pour les espaces de montagne durant l'âge du Bronze? Regards croisés sur les approches société-environnement dans les Pyrénées occidentales. Documents d'Archéologie Méridionale, 28, 34-45.

Cugny, C., Mazier, F., \& Galop, D. (2010). Modern and fossil non-pollen palynomorphs from the Basque mountains (western Pyrenees, France): The use of coprophilous fungi to reconstruct pastoral activity. Vegetation History and Archaeobotany, 19, 391-408.

Faure, E., \& Galop, D. (2011). La fin du paradigme du désert landais : histoire de la végétation et de l'anthropisation à partir de l'étude palynologique de quelques lagunes de la Grande Lande. In Merlet J-C. et Bost J-P. édt. « De la lagune à l'Airial. Le peuplement de la Grande-Lande » Aquitania suppl. 24, 43-59.

Galop, D. (1998). La forêt, l'homme et le troupeau dans les Pyrénées. 6000 ans d'histoire de l'environnement entre Garonne et Méditerranée. GEODE-LET-FRA.M.ESPA. Toulouse.

Galop, D. (2000). La croissance médiévale sur le versant nord des Pyrénées à partir des données palynologiques. In M. Berthe et \& B. Cursente (Eds.), Villages Pyrénéens Morphogenèse d'un habitat de montagne (pp. 45-54). CNRS, UTM.

Galop, D. (2001). Les apports de la palynologie à l'histoire rurale. La longue durée des activités agropastorales pyrénéennes. Etudes rurales, 153(154), 127-138.

Galop, D. (2005). Les transformations de l'environnement pyrénéen durant l'Antiquité: l'état de la question à la lumière des données polliniques. Aquitania, 13, 317-327.

Galop, D., Carozza, L., Marembert, F., \& Bal, M.-C. (2007). Activités pastorales et climat durant l'âge du Bronze dans les Pyrénées: l'état de la question à la lumière des données environnementales et archéologiques. In H. Richard, et al. (Eds.), Environnements et cultures à l'âge du Bronze en Europe occidentale (pp. 107-119). Editions du CTHS. 
Galop, D., \& Jalut, G. (1994). Differential human impact and vegetation history in two adjacent Pyrenean valleys in the Ariège basin, southern France, from 3000 B.P. to the present. Vegetation History and Archaeobotany, 3, 225-244.

Galop, D., Mazier, F., Lopez-Saez, J.-A., \& Vanniere, B. (2004). Palynologie et histoire des activités humaines en milieu montagnard. Bilan provisoire des recherches et nouvelles orientations méthodologiques sur le versant nord des Pyrénées. Archéologie du midi médiéval, 21, 159-170.

Galop, D., Tual, M., Monna, F., Dominik, J., Beyrie, A., \& Marembert, F. (2001). Cinq millénaires de métallurgie en montagne basque. Les apports d'une démarche intégrée alliant palynologie et géochimie isotopique du plomb. Sud-Ouest Européen, 11, 3-15.

Galop, D., Vannière, B., \& Fontugne, M. (2002). Fires and human activities since 4500 BC on the northern slope of the Pyrénées recorded in the peat bog of Cuguron (Central Pyrennes). In S. Thiébault (Ed.), Charcoal Analysis, Methodological approaches, Palaeocological results and wood uses (pp. 43-51). BAR International Series 1063.

Galop, D., Vannière, B., \& Lopez-Saez, J. A. (2003). Des abattis-brûlis néolithiques au système agro-pastoral pyrénéen actuel. Pirineus $i$ veins al $3 r$ mil.lenni AC, XII Colloque international de préhistoire de Puigcerda (pp. 261-274). Institut d'estudis ceretans.

Galop, D., \& Vaquer, J. (2004). Regards croisés sur les premiers indices de l'anthropisation en domaine pyrénéen. In H. Richard (dir.), Néolithisation précoce. Premières traces d'anthropisation du couvert végétal à partir des données polliniques (Vol. 7, pp. 179-194). Presses Universitaires de Franche-Comté. Besançon, Annales littéraires, 777; Série "Environnement, sociétés et archéologie".

Gellatly, A. F., Grove, J. M., \& Switsur, V. R. (1992). Mid-Holocene glacial activity in the Pyrénées. Holocene, 2, 266-270.

Gobet, E., Tinner, W., Hochuli, P. A., van Leeuwen, J. F. N., \& Ammann, B. (2003). Middle to late Holocene vegetation history of the Upper Engadine (Swiss Alps): The role of man and fire. Vegetation History and Archaeobotany, 12, 143-163.

Guenet, P. (1995). Analyse palynologique du sondage du petit Castelou. In J. Guilaine (dir.), Temps et espace dans le bassin de l'Aude du Néolithique à l'âge du Fer (pp. 334-341). Centre d'Anthropologie, Toulouse.

Guilaine, J. (2003). De la vague à la tombe. La conquête néolithique de la Méditerranée (pp. 375). Editions du Seuil.

Haas, J. N., Richoz, I., Tinner, W., \& Wick, L. (1998). Synchronous Holocene climatic oscillations recorded on the Swiss plateau and at timberline in the Alps. Holocene, 8, 29-40.

Jalut, G. (1995). Analyse pollinique de sédiments holocènes de l'étang de Capestang (Hérault). In J. Guilaine (dir.), Temps et espace dans le bassin de l'Aude du Néolithique à l'âge du Fer (pp. 293-303). Centre d'Anthropologie: Toulouse.

Jalut, G., Esteban-Amat, A., Bonnet, L., Gauquelin, T., \& Fontugne, M. (2000). Holocene climatic changes in the western Mediterranean, from south-east France to south-east Spain. Palaeogeography, Palaeoclimatology, Palaeoecology, 160, 255-290.

Lopez-Garcia, P., \& Lopez-Saez, J. A. (2000). Le paysage et la phase épipaléolithique-mésolithique dans les pré-Pyrénées aragonaises et le bassin moyen de l'Èbre à partir de l'analyse palynologique. Les derniers chasseurs-cueilleurs d'Europe occidentale (13000-5500 av. J.-C.) (Vol. 1, pp. 59-69). Presses Universitaires de Franche-Comté. Besançon, Annales littéraires, 699; Série "Environnement, sociétés et archéologie".

Magny, M. (2004). Holocene climate variability as reflected by mid-European lake-level fluctuations and its probable impact on prehistoric human settlements. Quaternary International, $113,65-79$.

Marembert, F. (2000). La grotte de Mikelauen-Zilo, Paléoenvironnement et dynamiques de l'anthropisation en Montagne basque (pp. 71-87). PCR, Rapport intermédiaire 2000. Service Régional de l'Archéologie d'Aquitaine.

Mazier, F., Galop, D., Brun, C., \& Buttler, A. (2006). Modern pollen assemblages from grazed vegetation in the western Pyrenees, France: A numerical tool for more precise reconstruction of past cultural landscapes. Holocene, 16, 91-103. 
Mazier, F., Galop, D., Gaillard, M.-J., Rendu, C., Cugny, C., Legaz, A., et al. (2009). Multidisciplinary approach to reconstruct pastoral activities. An example from the Pyrenean Mountains (Pays Basque). Holocene, 19, 171-178.

Monna, F., Galop, D., Carozza, L., Tual, M., Beyrie, A., Marembert, F., et al. (2004). Environmental impact of early basque mining and smelting recorded in a high ash minerogenic deposit. Science of the Total Environment, 327, 197-214.

Planchais, N. (1985). Analyses polliniques du remplissage holocène de la lagune de Canet (Plaine du Roussillon, Pyrénées-Orientales). Ecologia Meditteranea, XI(1), 117-127.

Rendu, C. (2003). La montagne d'Enveig. Une estive pyrénéenne dans la longue durée. Éditions Trabucaire.

Rendu, C., Calastrenc, C., Le Couedic, M., Galop, D., Rius, D., Cugny, C., et al. (in press). Montagnes et campagnes d'Oloron dans la longue durée. Premiers résultats d'un programme interdisciplinaire? Aquitania.

Rius, D., Vannière, B., \& Galop, D. (2009). Fire frequency and agro-pastoral activities landscape management in the north-western pyrenean piedmont (France) since early neolithic $(8000 \mathrm{cal}$. BP). Holocene, 19(6), 1-13.

Tinner, W., Lotter, A. F., Ammann, B., Conedera, M., Hubschmid, P., van Leeuwen, J. F. N., et al. (2003). Climatic change and contemporaneous land-use phases north and south of the alps 2300 BC to 800 BC. Quaternary Science Reviews, 22, 1147-1460.

van Geel, B. (2001). Non-pollen palynomorphs. In J. Smol, H. Birks, \& W. Last (Eds.), Tracking environmental change using lake sediments (pp. 99-109). Dordrecht: Kluwer.

van Geel, B., Buurman, J., \& Waterbolk, H. T. (1996). Archaeological. and palaeoecological. indications of an abrupt climate change in the Netherlands, and evidence for climatological. teleconnections around 2650 BP. Journal of Quaternary Science, 11(6), 451-460.

van Geel, B., Raspopov, O. M., van der Plicht, J., \& Renssen, H. (1998). Solar forcing of abrupt climate change around 850 calendar BC. In B. J. Peister, T. Palmer, \& M. E. Bailey (Eds.), Natural catastrophes during Bronze Age civilisations (pp. 162-168). BAR International Series 728.

Vanniere, B., Galop, D., Rendu, C., \& Davasse, B. (2001). Feu et pratiques agropastorales dans les Pyrénées-Orientales: le cas de la montagne d'Enveitg (Cerdagne, P.-O., France). Sud-Ouest Européen, 11, 29-42.

Walsh, K., Court-Picon, M., Mocci, F., Segard, M., \& Palet-Martinez, J. M. (2007). Occupation de la montagne et transformation des milieux dans les Alpes méridionales au cours de l'Âge du Bronze: approche croisée des données palynologiques et archéologiques en Champsaur et Argentiérois (Hautes-Alpes, France). In C. Mordant, H. Richard, \& M. Magny (Eds.), Environnements et cultures à l'Âge du Bronze en Europe occidentale (pp. 89-106).

Walsh, K., \& Richer, S. (2006). Attitudes to altitude: changing meanings and perceptions within a "marginal" Alpine landscape - the integration of palaeoecological and archaeological data in a high altitude landscape in the French Alps. World Archaeology, 38(3), 436-454.

Walsh, K., Tzortzis, S., Mocci, F., Talon, B., Court-Picon, M., Dumas, V., et al. (2008). Dynamique du peuplement et activités agro-pastorales durant l'âge du Bronze dans les massifs du haut Champsaur et de l'Argentiérois (Hautes-Alpes). In D. Garcia \& H. Richard (Eds.), Le Peuplement de l'arc alpin (pp. 123-148).

Whitlock, C., \& Larsen, C. (2002). Charcoal as a fire proxy. In J. Smol, H. Birks, \& W. Last (Eds.), Tracking environmental change using lake sediments (pp. 75-98). Dordrecht: Kluwer. 